\title{
Field Observations, Petrography, and Microstructures of Granite from Abeokuta Southwestern Nigeria
}

\section{Terenska opažanja, petrografija in mikrostrukture granita iz Abeokuta v jugozahodni Nigeriji}

\author{
Ehitua Julius Oziegbe*, Olusegun Abimbola Aribike \\ Department of Geosciences, University of Lagos, Lagos, Nigeria \\ *Corresponding author: E-mail: eoziegbe@unilag.edu.ng
}

\begin{abstract}
English
The granite of Abeokuta is part of the Older Granite suite of the basement complex of southwestern Nigeria. Field observation has identified the granite as porphyritic in texture, with a preferred alignment of megacrysts of K-feldspar $>5 \mathrm{~cm}$ that are mostly euhedral to subhedral in shape. K-feldspar megacrysts are predominantly yellowish, but whitish and pinkish colouration has also been observed. The dark grey porphyritic, mafic rock composition occurs as enclaves within the granite, with phenocrysts having a preferred alignment as the enclosing granite. Also, K-feldspar megacrysts show zoning defined by concentric arrangement of inclusions of biotite relative to the crystal faces. Petrographic study shows the following minerals in order of abundance: K-feldspar, biotite, quartz, and plagioclase, with K-feldspar having a microperthitic intergrowth and biotite crystals aligned in a preferred direction. Evidence such as the crystal shape of K-feldspars, preferred alignment of K-feldspar phenocrysts, and concentric crystallographic arrangements of inclusions of biotite in K-feldspar support a magmatic/phenocrystic origin of K-feldspar megacrysts of Abeokuta granite rather than originating by growing in a solid state as porphyroblasts.
\end{abstract}

Keywords: megacrysts, microperthitic, K-feldspar, zoning, porphyroblasts

\section{Abstract in Povzetek}

Abeokutski granit pripada Starejšemu granitu Bazalnega kompleksa v jugozahodni Nigeriji. Glede na terenska opažanja ima granit porfirsko strukturo. Več kot 5 cm veliki evhedralni do subhedralni vtrošniki kalijevih glinencev kažejo usmerjenost. Vtrošniki kalijevih glinencev so večinoma rumenkasto obarvani, čeprav so prisotni tudi beli do rožnati kristali. V granitu se pojavljajo vključki temno sive porfirske mafične kamnine, ki vsebuje fenokristale $\mathrm{z}$ enako orientacijo kot jo imajo kristali kalijevih glinencev $\mathbf{v}$ okolnem granitu. Vtrošniki kalijevih glinencev nadalje kažejo conarno zgradbo, ki jo določa koncentrična razporeditev vključkov biotita. $S$ petrografsko preiskavo so bili določeni naslednji minerali, našteti od najpogostejših do najbolj redkih: kalijevi glinenci, biotit, kremen in plagioklazi. Kalijevi glinenci imajo mikropertitsko preraščanje. Kristali biotita so med seboj enako usmerjeni. Oblika kristalov kalijevih glinencev, preferenčna orientacija fenokristalov kalijevih glinencev in koncentrična razporeditev vključkov biotita v kalijevih glinencih so nekatere lastnosti, ki podpirajo magmatski/porfirski izvor vtrošnikov kalijevega glinenca v Abeokutskem granitu in ne porfiroblastično rast iz trdnih raztopin.

Ključnebesede: vtrošniki, mikropertit, kalijev glinenec, conarna rast, porfiroblasti 


\section{Introduction}

Granite is the most abundant rock in the continental crust. A-type granite is proposed to originate from the fractional crystallization of the upper mantle [1-6]. Abeokuta, the study area, shares a boundary with the sedimentary rocks of the Dahomey Basin. Large crystals of K-feldspar with the preferred alignment typifies the granite of Abeokuta (Figure 1). Arguments have been put forward to suggest the origination of these megacrysts in granite. In some of the literature, it is agreed that phenocrysts are formed through early growth by crystallization from the molten portion of magma [7-11], while the later developing porphyroblasts arise from a water-rich fluid phase usually in the subsolidus environment [12-16]. The current study uses field observations and petrographic
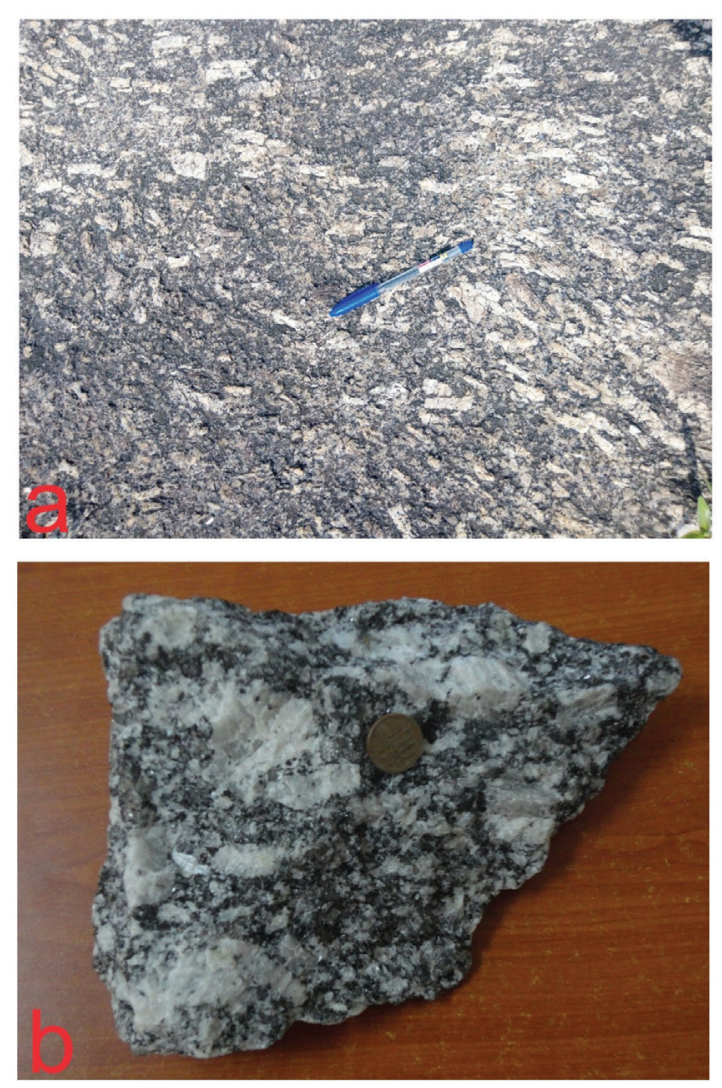

Figure 1: a) Field photograph showing dispersed $K$-feldspar megacrysts with the preferred alignment from Abeokuta. Megacryts are subhedral to euhedral b) Hand specimen sample of porphyritic granite from Abeokuta showing a large phenocryst of K-feldspar in a matrix of biotite. features to determine the origin of K-feldspar megacrysts in the granite of Abeokuta.

\section{Geological Setting}

Nigeria is located within the section of PanAfrican reactivation $600+150 \mathrm{Ma}[17,18]$ to the east of the West African craton. The older granite suite of Nigeria comprises for the most part tonalitic to granitic calc-alkaline intrusions which were emplaced at a period of about $800-$ 500 Ma ago [19-22]. The Older Granite suite of Nigeria has been described as a high-level, I-type intrusion [23-25]. The phrase 'Older Granite' was coined by Falconer [26] to separate the deep-seated, often concordant granites of the Precambrian basement complex of Nigeria from the highly discordant tin-bearing granite which is found in Northern Nigeria. Older Granite is one of the substantial rock units identified in the Precambrian basement complex of Nigeria [27]. Older Granite suites have a wide range of composition that varies

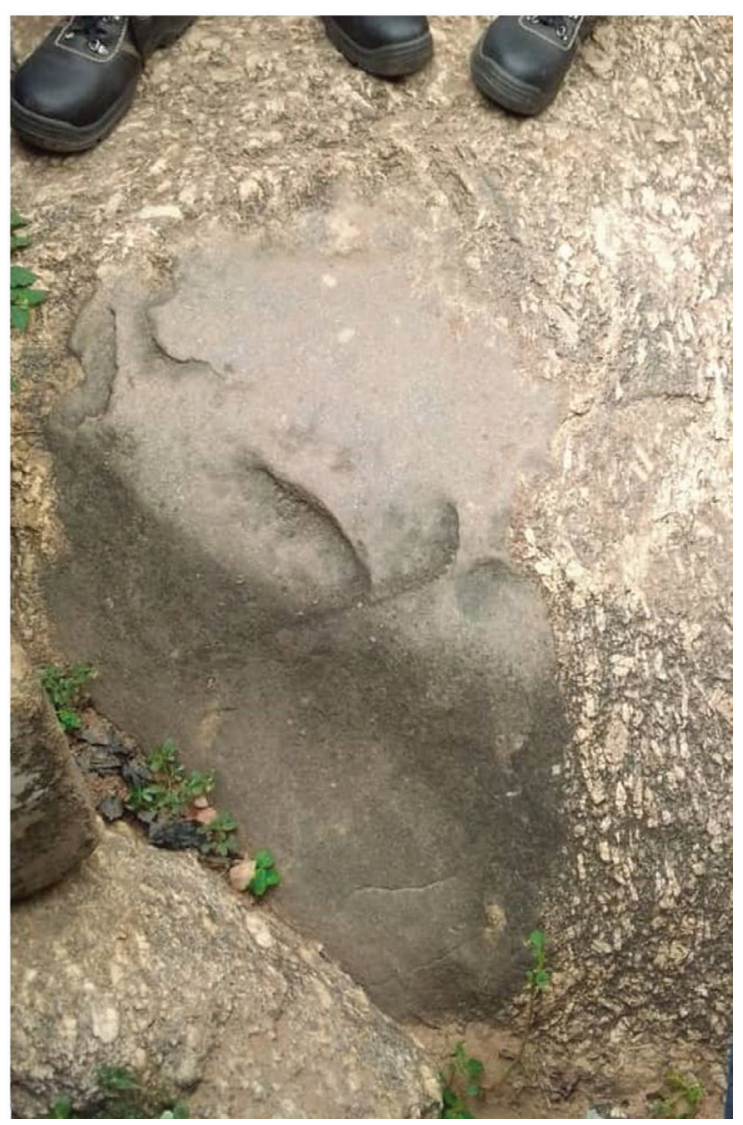

Figure 2: Field photograph showing a xenolith of porphyritic mafic rock within a felsic, porphyritic granite. 
from granite through granodiorite, adamellite/ quartz monzonite to syenite [27]. The granitic rock of Abeokuta is porphyritic in texture, with phenocrysts of K-feldspar aligned in the preferred direction and thus defining foliation (Figure 1a). Where aligned, the phenocrysts trend in a NW-SE direction on the field. There are quatzo-feldspathic veins and pegmatitic veins of different dimensions running through the granite. Xenoliths of porphyritic mafic rock composition exist within the main porphyritic granite (Figure 2). The sizes of phenocrysts observed on the field vary from a few millimeters to about $10.5 \mathrm{~cm}$ in length (Figure 3a).

Granite has a greater amount of K-feldspar megacrysts (Figure $3 \mathrm{a}$ and $3 \mathrm{~b}$ ) as compared to matrix and can be described as megacrystdominated. Some K-feldspar megacrysts are zoned (Figures 3c-3h), with inclusions of biotitedefining zonation. The inclusions of biotite are arranged in a concentric pattern along the crystal faces of the zoned megacrysts (Figures $3 c, 3 e$, and 3f). K-feldspar megacrysts vary in colour from yellowish, whitish, and in some cases pinkish colouration. The associated mafic porphyritic rock component also shows zoned crystals of K-feldspars (Figures $3 g$ and $3 \mathrm{~h}$ ). The mafic rock components, which occur as enclaves within the porphyritic granite, have micro-phenocrysts aligned in the same direction as the megacrysts in the porphyritic granite (Figure 4 ).

\section{Materials and methods}

Thin sections of porphyritic granite were prepared at the Department of Geology, Obafemi Awolowo University in Ife, Nigeria. The petrographic study was carried out at the Department of Geosciences, University of Lagos using a polarizing microscope, and optical properties of the minerals were studied under both plane-polarized light (PPL) and crosspolarized light (XPL).

\section{Results}

\section{Petrography}

The granite comprises the following minerals in order of abundance: K-feldspar, biotite, quartz, and plagioclase with apatite occurring as an accessory mineral. The crystals of K-feldspar are subhedral to anhedral in shape and occur as phenocrysts in a matrix of quartz and biotite (Figure 5). K-feldspar is poikilitic, having inclusions of biotite (Figure 5a). A cross-hatched twinning is an indication of the presence of microcline, a type of K-feldspar (Figure 5b). The plagioclase feldspar has polysynthetic twinning, also referred to as albite twinning (Figure 5c). Plagioclase shows a high level of albitization (Figure $5 c$ ). K-feldspar exhibits perthitic texture (Figures $5 \mathrm{~d}$ and $5 \mathrm{e}$ ). Quartz crystals occur as inclusions in phenocrysts of K-feldspar (Figure 5e), and exhibit a symplectic texture between K-feldspar and plagioclase (Figure 5f). Biotite has crystals with a preferred alignment (Figures 5g and 5h).

\section{Discussion}

Megacryst K-feldspars are prominent features in Abeokuta granite. For growth of crystals, essential components in the magma must diffuse through the melt to the crystal-melt interface, and also excess or excluded components need to diffuse away from the interface. It has been shown that diffusivities in silicate melts usually reduce in the sequence $\mathrm{Na} \geq \mathrm{K}>$ $\mathrm{Ca}>\mathrm{Al}>>\mathrm{Si}[28,29]$. Therefore, the rate-limiting event necessary for the crystallization of feldspars and quartz is the attainment of the correct percentages of Si:Al available at the crystal-melt margins. To this end, the megacrystic nature of K-feldspars means that the composition of K-feldspar is highly similar to that of the granitic liquid in terms of the major components that diffuse slowly in silicate melts. Other granite-forming minerals do not share this compositional similarity with the granitic liquid. The time at which K-feldspar starts to crystallize also depends on the bulk chemical composition of the magma. More alkalic magmas will naturally precipitate K-feldspar earlier than those of less-K-rich compositions [30]. Difficulty in the nucleation of K-feldspar has been given as the reason why $\mathrm{K}$-feldspar forms megacrysts; once nucleation commences, it grows rapidly, thus a small number of very large crystals is formed [31]. The phenocrysts of the K-feldspars can be termed megacrysts 

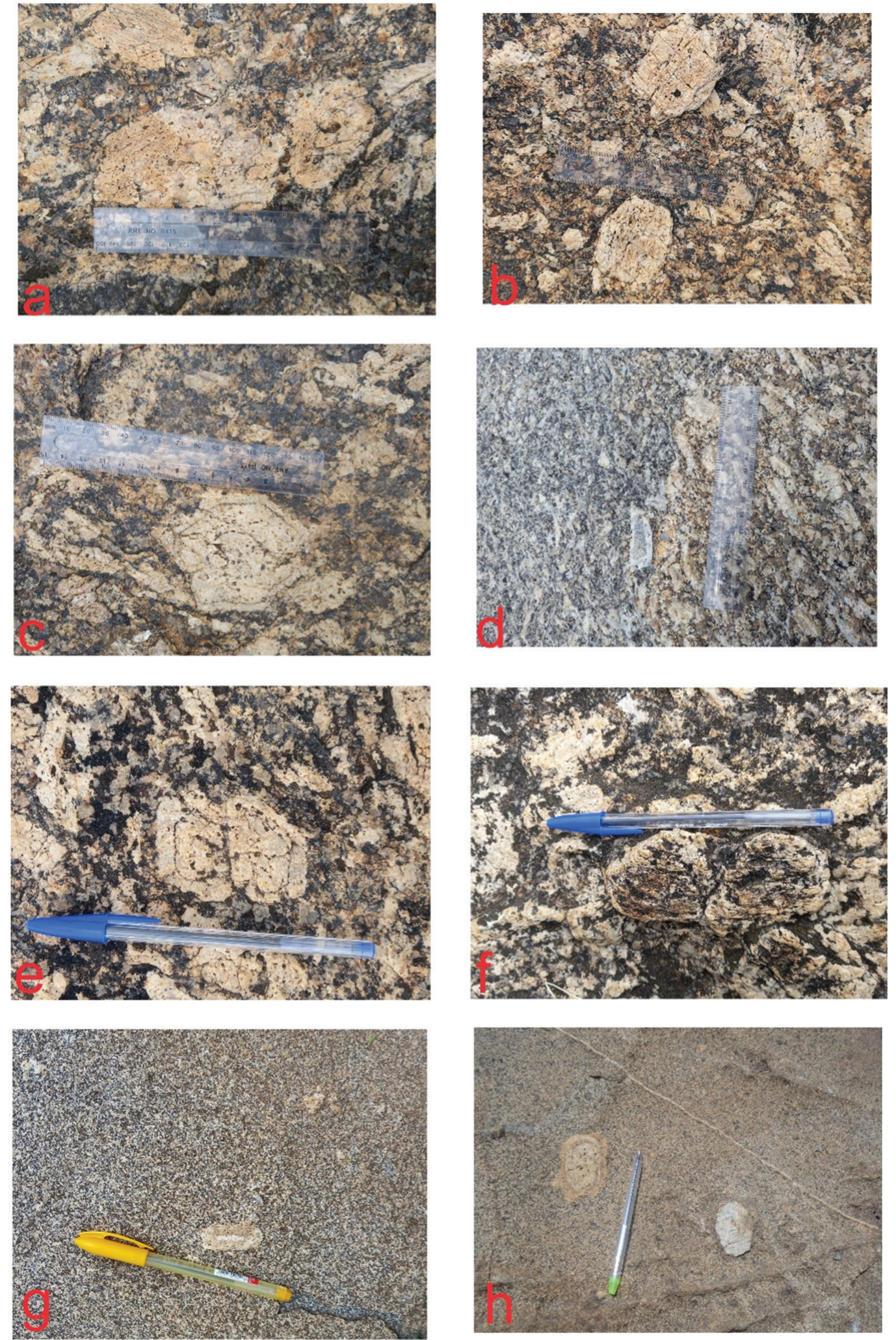

Figure 3: Field photographs showing: a) megacrysts of K-feldspar, b) subhedral-euhedral megacrysts of K-feldspar, c) zoned crystals with concentric inclusions of biotite, d) zoned crystals of $K$-feldspar with a core rich in biotite inclusion, e) $K$-feldspar magacrysts with inclusions of biotite-defining zonation, f) Zoned K-feldspar crystal with inclusions of biotite, $g$ ) zoned crystal of $K$-feldspar in porphyritic mafic rock, $h$ ) matrix-dominated porphyritic mafic rock with zoned megacrysts of $K$-feldspar. 


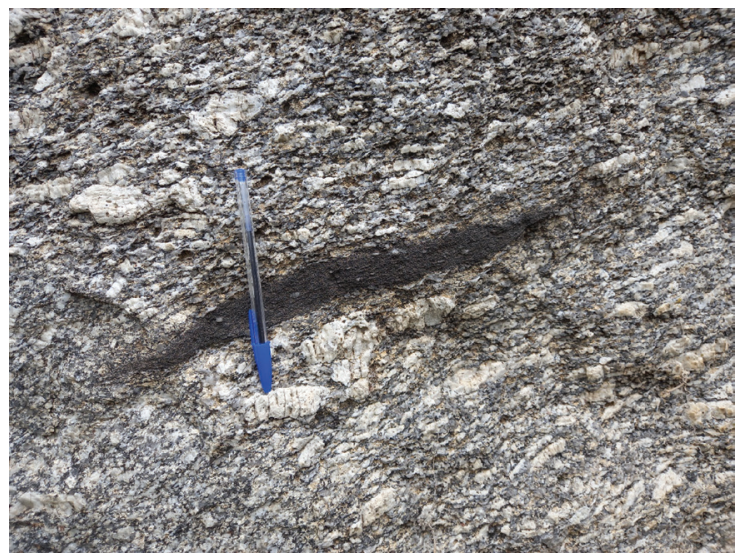

Figure 4: Field photograph showing enclaves of a pophyritic mafic rock component within porphyritic granite. The micro-phenocrysts, megaphenocrysts, and biotite crystals are all aligned in the same direction.
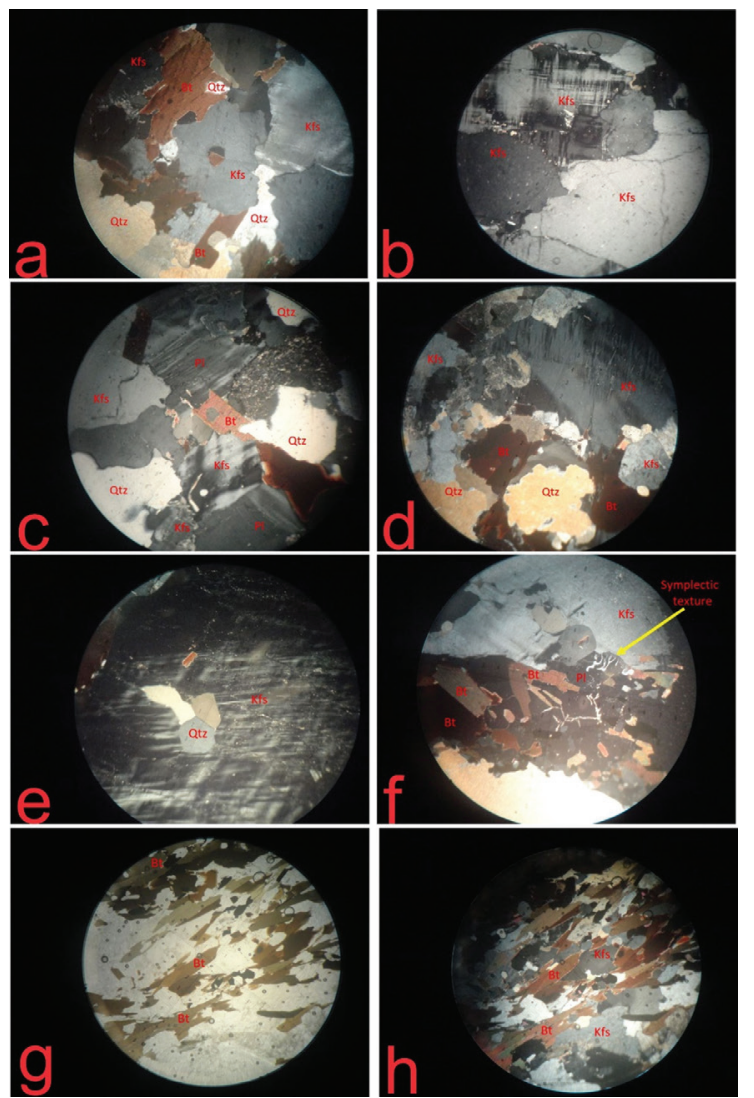

Figure 5: Photomicrographs of porphyritic granite showing a) inclusions of biotite in $K$-feldspar (Kfs), XPL b) tartan twining in $K$-feldspar (Kfs), XPL c) albitization of plagioclase feldspar (Kfs), $X P L$ d) perthitic texture in K-feldspar (Kfs), XPL e) K-feldspar with perthitic intergrowth and inclusions of quartz (Qtz), XPL $f$ ) symplectic texture between $K$-feldspar and plagioclase (PI), XPL g) biotite (Bt) crystals with a preferred alignment, $P P L h$ ) biotite (Bt) and K-feldspar (Kfs) in close association, XPL. on the basis of their size, which is several times larger than the plagioclase. This might be due to the low rate of nucleation and the rapid growth rate $[9,32]$. However, Moore and Sisson [33] have proposed that K-feldspar grows into larger megacrysts than other minerals in granite because of the similarities in the composition of K-feldspar and the granitic components that diffuse slowly in silicate melts. In most zones, a preferred alignment of the K-feldspar megacrysts forms (Figure 1a), defining foliation. Foliated granite has been reported in the members of the Older Granite suite in other parts of the Basement Complex of Nigeria [34, $35,19,36]$. These foliations in granitoids can form through magmatic flow $[37,38]$. The preferred alignment of crystals suggests that the magma attained a high viscosity and could have occurred in the later stage of crystallization for the preferred orientation to be preserved [39]. Zoning is a common feature in the K-feldspar megacrysts (Figures 3c-3h). Dark inclusions of biotite are displayed in internal zones aligned to the outer margins of megacrysts (Figures $3 c$ and 3e). A number of igneous microtextural features, such as simple twinning and concentric arrangements of inclusions, are typical of K-feldspar megacryst of magmatic origin [8, 40, 41]. Microgranite enclaves have also been (Figure 4) derived, which implies that the megacrysts moved as independent crystals suspended in liquid, and therefore did not develop in situ [42]. The elongation of such microgranitoid enclaves (Figure 4), without the presence of plastic contortion of the minerals provides evidence of magmatic flow $[38,43]$. The inclusions within the megacrysts are far smaller than their matrix equivalents, and thus show characteristics specific to magmatic growth, which includes zonal alignment (Figures $3 c$ and $3 f$ ) and euhedral shape [8]. K-feldspar megacrysts have been interpreted to be early crystallizing phases [16]. Symplectic intergrowth between $\mathrm{K}$-feldspar and plagioclase can be observed in thin section (Figure 5f), which provides us with a clue about the final crystallization process in the granite under study. Symplectic texture has been reported in granitoids from southwestern Nigeria [44]. Symplectic texture in petrology is characterized by the intergrowth of two minerals that crystallized simultaneously [45]. 
Symplectic intergrowth in granite has been described by different authors across continents [46, 47]. Replacement of plagioclase by K-feldspar (Figure 5c), as described by Collins [48], appears to be a very common phenomenon. Replacement of plagioclase by K-feldspar at low temperatures has been reported [49], but a high temperature alteration of plagioclase to K-feldspar is also possible [49, 50]. For instance, at a temperature of about $25-350^{\circ} \mathrm{C}$, plagioclase feldspars are altered to sericite through weathering [51]. Some of the quartz crystals exhibit a wavy form of extinction. There are minor fractures on some K-feldspar megacrysts (Figure 3c) and micro-fractures on K-feldspar crystals (Figure $5 \mathrm{~b}$ ), which are evidences of deformation. The fact that biotite occurs as inclusions in the K-feldspar follows the Bowen reaction series in which the biotite crystalizes first at a higher temperature before the K-feldspar crystalizes at a much lower temperature (Figure 5a). The K-feldspar has many of the other minerals in the rock present as inclusions, which is an indication of the late-stage crystallization of K-feldspar [8]. The alkali feldspar shows flame perthitic to mesoperthitic structure (Figures $5 \mathrm{~d}$ and $5 \mathrm{e}$ ). The formation of perthite has been explained to be a replacement-type reaction (Na-K exchange) that takes place between K-feldspar and plagioclase in an environment of low-moderate differential stress usually accompanying rapid cooling [52-56]. The presence of exsolution lamellae (Figures $5 \mathrm{~d}$ and $5 \mathrm{e}$ ) could be found in recrystallized K-feldspar formed at hypersolvus temperatures $[37,57]$. Several researchers have used microtextures, such as perthite and myrmekite, as tools to investigate the cooling mechanism of rocks [58-61], which can also be linked to exsolution and hydrothermal subsolidus activity.

\section{Conclusion}

Observations such as the crystal shape of K-feldspars and concentric crystallographic arrangements of inclusions of biotite in K-feldspar have provided evidence supporting a magmatic/phenocrystic origin for K-feldspar megacrysts in Abeokuta granite rather than originating while growing in a solid state as in the formation of porphyroblasts. K-feldspar's inclusion of other minerals and the preferred alignment of K-feldspar magacrysts attributed to magmatic flow suggest late crystallization of K-feldspar.

\section{References}

[1] Turner, S.P., Foden, J.D., Morrison, R.S. (1992):

Derivation of some A-type magmas by fractionation of basaltic magma: an example from the Padthaway Ridge, South Australia. Lithos, 28(2), pp. 151-179. Doi.org/10.1016/0024-4937(92)90029-X

[2] Atherton, M.P. (1993): Granite magmatism. Journal of the Geological Society, 150(6), pp. 1009-1023. Doi.org/10.1144/gsjgs.150.6.1009

[3] Soesoo, A. (2000): Fractional crystallization of mantlederived melts as a mechanism for some I-type granite petrogenesis: an example from Lachlan Fold Belt, Australia. Journal of the Geological Society, 157(1), pp. 135-149. Doi.org/10.1144/jgs.157.1.135

[4] Jarrar, G.H., Manton, W.I., Stern, R.J., Zachmann, D. (2008): Late Neoproterozoic A-type granites in the northernmost Arabian-Nubian Shield formed by fractionation of basaltic melts. Geochemistry, 68(3), pp. 295-312. Doi.org/10.1016/j.chemer.2006.09.002

[5] Namur, O., Charlier, B., Toplis, M.J., Higgins, M.D., Hounsell, V., Liégeois, J.P., Vander Auwera, J. (2011): Differentiation of tholeiitic basalt to A-type granite in the Sept Iles layered intrusion, Canada. Journal of Petrology, 52(3), pp. 487-539. Doi.org/10.1093/ petrology/egq088

[6] Zhou, G., Wu, Y., Wang, H., Qin, Z., Zhang, W., Zheng, J., Yang, S. (2017): Petrogenesis of the Huashanguan A-type granite complex and its implications for the early evolution of the Yangtze Block. Precambrian Research, 292, pp. 57-74. DOI.org/10.1016/j. precamres.2017.02.005

[7] Kerrick, D.M. (1969): K-feldspar megacrysts from a porphyritic quartz monzonite central Sierra Nevada, California. American Mineralogist: Journal of Earth and Planetary Materials, 54(5-6), pp. 839-848.

[8] Vernon, R.H. (1986): K-feldspar megacrysts in granites-phenocrysts, not porphyroblasts. Earth-Science Reviews, 23(1), pp. 1-63. Doi.org/10.1016/0012-8252(86)90003-6

[9] Cox, R.A., Dempster, T.J., Bell, B.R., Rogers, G. (1996). Crystallization of the Shap Granite: Evidence from zoned K-feldspar megacrysts. Journal of the Geological 
Society, 153(4), pp. 625-635. Doi.org/10.1144/ gsjgs.153.4.0625

[10] Johnson, B.R., Glazner, A.F. (2010): Formation of $\mathrm{K}$-feldspar megacrysts in granodioritic plutons by thermal cycling and late-stage textural coarsening. Contributions to Mineralogy and Petrology, 159(5), pp. 599-619. Doi.org/10.1007/s00410-009-0444-z

[11] Winter, J.D. (2001): An Introduction to Igneous and Metamorphic Petrology. Prentice Hall, Upper Saddle River, New Jersey, 699 pp.

[12] Oyawoye, M.O. (1962): The petrology of the district around Bauchi, Northern Nigeria. The Journal of Geology, 70(5), pp. 604-615. Doi/ abs/10.1086/626855

[13] Oyawoye, M.O. (1967): The petrology of a potassic syenite and its associated biotite pyroxenite at Shaki, Western Nigeria. Contributions to Mineralogy and Petrology, 16(2), pp. 115-138.

[14] Dickson, F.W., Sabine, C.P. (1967): Barium zoned large K-feldspars in quartz monzonites of eastern and southeastern California [abs]. Geological Society of America Special Paper, 115, p. 323.

[15] Oyawoye, M.O. (1972): The basement complex of Nigeria. African Geology, I. Ibadan University Press, Ibadan , pp. 67-99.

[16] Johnson, B.R., Glazner, A.F., Coleman, D.S. (2006): Significance of K-feldspar megacryst size and distribution in the Tuolumne Intrusive Suite, California [abs.]. In: 102nd Annual Meeting of the Cordilleran Section, Geological Society of America: Abstracts with Programs; Vol. 38, No. 5, p. 93.

[17] Kennedy, W.Q. (1964): The structural differentiation of Africa in the Pan-African (+/-500 my) tectonic episode. University of Leeds, Research Institute of African Geology, Annual Report on Scientific Results; 8, pp. 48-49.

[18] Clifford, T.N. (1970): The Structural Framework of Africa. In: African Magmatism and Tectonics. Clifford, T.N., Gass, I.G. (eds.). Oliver and Boyd: Edinburgh, pp. 1-26.

[19] Van Breemen, O., Pidgeon, R.T., Bowden, P. (1977): Age and isotopic studies of some Pan-African granites from North-central Nigeria. Precambrian Research, 4(4), pp. 307-319. Doi.org/10.1016/0301-9268(77)90001-8

[20] Ogezi, A.E.O. (1977): Geochemistry and geochronology of basement rocks from northwestern Nigeria. Ph. D. Thesis. University of Leeds, Department of Earth Sciences: Leeds, 298 pp.

[21] Grant, N.K. (1978): Structural distinction between a metasedimentary cover and an underlying basement in the 600-my-old Pan-African domain of northwestern Nigeria, West Africa. Geological Society of America Bulletin, 89(1), pp. 50-58. Doi.org/10.1130/0016-7606(1978)89\%3C5 0:SDBAMC\%3E2.0.CO;2

[22] Cahen, L., Snelling, N.J., Delhal, J., Vail, J.R., Bonhomme, M., Ledent, D. (1984): The West African Craton: The Guinea Rise. In: The Geochronology and Evo1ution of Africa, Cahen L., Snelling N.J., Delhal J., Vail J.R., et al. (eds.). Clarendon Press,;z Oxford, UK, pp. 296-311.

[23] Chappell, B.W. (1974): Two contrasting granite types. Pacific Geology, 8, pp. 173-174.

[24] Pitcher, W.S. (1979a): The nature, ascent and emplacement of granitic magmas. Journal of the Geological Society, 136(6), pp. 627-662. Doi. org/10.1144/gsjgs.136.6.0627

[25] [Pitcher, W.S. (1979b): Comments on the geological environments of granites. In: Origin of Granite Batholiths Geochemical Evidence, Atherton, M.P., Tarneyh, J. (eds.). Birkhäuser: Boston, pp. 1-8. Doi.org/10.1007/978-1-4684-0570-5_1

[26] Falconer, J.D. (1911): The Geology and Geography of Northern Nigeria. MacMillan: London, 295 pp.

[27] Rahaman, M.A. (1976): Review of the basement geology of Southwestern Nigeria. In: Geology of Nigeria, Kogbe, C.A. (ed.), Elizabethan Publishing Company: Lagos, pp. 41-58.

[28] Hofmann, A.W. (1980): Diffusion in natural silicate melts: A critical review. Physics of Magmatic Processes, Hargraves, R.B. (ed.). Princeton University Press: Princeton, New Jersey, pp. 385-417.

[29] Hofmann, A.W., Hargraves, R.B. (2014): Diffusion in natural silicate melts: a critical review. In: Physics of Magmatic Processes, Hargraves, R.B. (ed.). Princeton University Press: Princeton, New Jersey, pp. 385-418. Doi.org/10.1515/9781400854493.385

[30] Williams, H., Turner, F.J., Gilbert, C.M. (1982): Petrography: An Introduction to the Study of Rocks in Thin Section. W. H. Freeman: San Francisco \& Oxford, $626 \mathrm{pp}$.

[31] Swanson, S.E. (1977): Relation of nucleation and crystal-growth rate to the development of granitic textures. American Mineralogist, 62(9-10), pp. 966-978.

[32] Paterson, S.R., Vernon, R.H., Zak, J. (2005): Mechanical instabilities and physical accumulation of K-feldspar megacrysts in granitic magma, Tuolumne Batholith, California, USA. The Journal of the Virtual Explorer, 18, pp. 1-18. Doi.org/10.3809/ jvirtex.2005.00114

[33] Moore, J.G., Sisson, T.W. (2008): Igneous phenocrystic origin of K-feldspar megacrysts in granitic rocks 
from the Sierra Nevada batholith. Geosphere, 4(2), pp. 387-400. Doi.org/10.1130/GES00146.1

[34] Trustwell, J.F., Cope, R.N. (1963): The Geology of Parts of Niger and Zaria Provinces. Northern Nigeria GSN Bulletin, 29, 53pp.

[35] Oyawoye, M.O. (1964): The geology of the Nigerian Basement Complex-a survey of our present knowledge of them. Journal of Mining Geology and Metal, 1(2), pp. 87-103.

[36] Tubosun, I.A., Lancelot, J.R., Rahaman, M.A., Ocan, O. (1984): U-Pb Pan-African ages of two charnockite-granite associations from southwestern Nigeria. Contributions to Mineralogy and Petrology, 88(1), pp. 188-195. Doi.org/10.1007/ BF00371422

[37] Paterson, S.R., Vernon, R.H., Tobisch, O.T. (1989): A review of criteria for the identification of magmatic and tectonic foliations in granitoids. Journal of Structural Geology, 11(3), pp. 349-363. Doi.org/10.1016/0191-8141(89)90074-6

[38] Vernon, R.H. (2000): Review of microstructural evidence of magmatic and solid-state flow. Visual Geosciences, 5(2), pp. 1-23. Doi.org/10.1007/ s10069-000-0002-3

[39] Paterson, S.R., Fowler Jr, T.K., Schmidt, K.L., Yoshinobu, A.S., Yuan, E.S., Miller, R.B. (1998): Interpreting magmatic fabric patterns in plutons. Lithos, 44(1-2), pp. 53-82. Doi.org/10.1016/ S0024-4937(98)00022-X

[40] Vernon, R.H. (1999): Quartz and feldspar microstructures in metamorphic rocks. Canadian Mineralogist, 37(2), pp. 513-524.

[41] Vernon, R.H. (2004): A Practical Guide to Rock Microstructure. Cambridge University Press: Cambridge, UK, 440 pp.

[42] Vernon, R.H., Paterson, S.R. (2008): How late are K-feldspar megacrysts in granites? Lithos, 104(1-4), pp. 327-336. Doi.org/10.1016/j.lithos.2008.01.001

[43] Tobisch, O.T., McNulty, B.A., Vernon, R.H. (1997): Microgranitoid enclave swarms in granitic plutons, central Sierra Nevada, California. Lithos, 40(2-4), pp. 321-339. Doi.org/10.1016/S0024-4937(97)00004-2

[44] Oziegbe, E.J., Ocan, O.O., Adebisi, A.P. (2020): Petrography and Microtextural Characteristics of Granodiorite from Wasimi, Southwestern Nigeria. Earth Sciences Malaysia (ESMY), 4(2), pp. 82-89. Doi.org/10.26480/esmy.02.2020.51.58

[45] Allaby, M. (2013): A Dictionary of Geology and Earth Sciences, $4^{\text {th }}$ edition. Oxford University Press: Oxford, UK, 660 pp.
[46] Pandit, D. (2015): Geochemistry of feldspar intergrowth microtextures from paleoproterozoic granitoids in Central India: implications to exsolution processes in granitic system. Journal of the Geological Society of India, 85(2), pp. 163-182. Doi.org/10.1007/s12594-015-0204-9

[47] Abart, R., Heuser, D., Habler, G. (2014): Mechanisms of myrmekite formation: case study from the Weinsberg granite, Moldanubian zone, Upper Austria. Contributions to Mineralogy and Petrology, 168(5), p. 1074. Doi.org/10.1007/ s00410-014-1074-7

[48] Collins, L.G. (2003): Transition from magmatic to $\mathrm{K}$-metasomatic processes in granodiorites and Pyramid Peak granite, Fallen Leaf Lake 15-Minute Quadrangle, California, USA. Myrmekite and Metasomatic Granite, ISSN 1526-5757, Internet publication, no. 48.

[49] Morad, S., El-Ghali, M.A.K., Caja, M.A., Sirat, M., Al-Ramadan, K., Mansurbeg, H. (2010): Hydrothermal alteration of plagioclase in granitic rocks from Proterozoic basement of SE Sweden. Geological Journal, 45, pp. 105-116. Doi.org/10.1002/gj.1178

[50] Cox, K.G. (2013): The Interpretation of Igneous Rocks. Springer Science \& Business Media: New York, 450 pp.

[51] Collins, L.G., Collins, B.J. (2013): Origin of myrmekite as it relates to $\mathrm{K}-, \mathrm{Na}-$, and Ca-metasomatism and the metasomatic origin of some granite masses where myrmekite occurs. Contribbutions to Mineralalogy and Petrology, 213, pp. 123-156.

[52] Yund, R.A., McLaren, A.C. and Hobbs, B.E. (1974): Coarsening kinetics of the exsolution microstructure in alkali feldspar. Contributions to Mineralogy and Petrology, 48(1), pp. 45-55. Doi.org/10.1007/ BF00399109

[53] Yuguchi, T., Nishiyama, T. (2008): The mechanism of myrmekite formation deduced from steadydiffusion modeling based on petrography: Case study of the Okueyama granitic body, Kyushu, Japan. Lithos, 106(3-4), pp. 237-260. Doi.org/10.1016/j.lithos.2008.07.017

[54] Parsons, I., Lee, M.R. (2009): Mutual replacement reactions in alkali feldspars I: microtextures and mechanisms. Contributions to Mineralogy and Petrology, 157(5), pp. 641-661. Doi.org/10.1007/ s00410-008-0355-4

[55] Parsons, I., Magee, C.W., Allen, C.M., Shelley, J.M.G., Lee, M.R. (2009): Mutual replacement reactions in 
alkali feldspars II: trace element partitioning and geothermometry. Contributions to Mineralogy and Petrology, 157(5), pp. 663-687. Doi.org/10.1007/ s00410-008-0358-1

[56] Parsons, I., Gerald, J.D.F., Lee, J.K., Ivanic, T., GollaSchindler, U. (2010): Time-temperature evolution of microtextures and contained fluids in a plutonic alkali feldspar during heating. Contributions to Mineralogy and Petrology, 160(2), pp. 155-180. Doi.org/10.1007/s00410-009-0471-9

[57] Vernon, R.H., Williams, V.A., D’arcy, W.F. (1983): Grain-size reduction and foliation development in a deformed granitoid batholith. Tectonophysics, 92(1-3), pp. 123-145. Doi.org/10.1016/0040-1951(83)90087-2

[58] Harlov, D.E., Wirth, R. (2000): K-feldspar-quartz and K-feldspar-plagioclase phase boundary interactions in garnet-orthopyroxene gneiss's from the Val Strona di Omegna, Ivrea-Verbano Zone, northern Italy. Contributions to Mineralogy and
Petrology, 140(2), pp. 148-162. Doi.org/10.1007/ s004100000185

[59] Yuguchi, T., Nishiyama, T. (2007): Cooling process of a granitic body deduced from the extents of exsolution and deuteric sub-solidus reactions: Case study of the Okueyama granitic body, Kyushu, Japan. Lithos, 97(3-4), pp. 395-421.

Doi.org/10.1016/j.lithos.2007.01.005

[60] Nanda, J., Gupta, S., Mamtani, M.A. (2009): Analysis of deformation fabric in an alkaline complex (Koraput): Implications for time relationship between emplacement, fabric development and regional tectonics. Journal of the Geological Society of India, 74(1), pp. 78-94. Doi.org/10.1007/s12594-009-0093-x

[61] Yuguchi, T., Tsuruta, T., Nishiyama, T. (2011): Threedimensional cooling pattern of a granitic pluton II: The study of deuteric sub-solidus reactions in the Toki granite, Central Japan. Journal of Mineralogical and Petrological Sciences, 106(3), pp. 130-141. Doi.org/10.2465/jmps.100129b 